\title{
PENGARUH DEBT TO EQUITY RATIO (DER), RETURN ON ASSETS (ROA), RETURN ON EQUITY (ROE), DAN DIVIDEND PAYOUT RATIO (DPR) TERHADAP PRICE TO BOOK VALUE (PBV) PADA PERUSAHAAN LQ45 YANG TERDAFTAR DI BURSA EFEK INDONESIA PERIODE 2010-2013
}

\author{
Oleh : \\ MELATI PRATIWI SUDIRJO, SE \\ Program Studi Akuntansi - STIE Dr KHEZ Muttaqien \\ INDRA MAULANA, SE., MM \\ Program Studi Manajemen - STIE Dr KHEZ Muttaqien \\ melmel.pratiwi@gmail.com \\ indra.maulana1177@gmail.com
}

\begin{abstract}
Price to Book Value (PBV) or the price per book value ratio is the relationship between the stock market price and book value per share. This ratio indicates the company's ability to create value relative to the amount of capital invested. The higher PBV companies create value for shareholders. This ratio is also used as an indicator in determining the value of shares as consideration for investors in determining investment decisions. This study aimed to examine the effect of the variable Debt to Equity Ratio (DER), Return on Assets (ROA), Return on Equity (ROE), and Dividend Payout Ratio (DPR) to the Price to Book Value.

The population in this study is LQ45 categories listed companies in Indonesia Stock Exchange 2010-2013 period as many as 78 companies with sampling using purposive sampling and samples that meet the criteria are as many as 13 companies. The data in this study using panel data regression analysis (fixed effect) is applied with software Eviews 7.1. and hypothesis testing using $t$-statistic to test the partial coefficient of regression and $f$ statistic to examine the effect simultaneously with a significance level of $5 \%$.

The results showed that the variables PBV DER significantly influence the value of 0.01. ROA variables significantly influence the PBV with a significance value of 0.00. ROE significantly influence the PBV with a significance value of 0.04. But the House did not influence significantly the variables with a significance value of 0.95 . Predictive ability of the four variables to the PBV is at $99 \%$ as indicated by the R-Squared of $99 \%$ while the remaining $1 \%$ is influenced by other factors not included in the model study.
\end{abstract}

Keywords: Debt to Equity Ratio (DER), Return on Assets (ROA), Return on Equity (ROE), Dividend Payout Ratio (DPR), and Price to Book Value (PBV). 


\section{PENDAHULUAN}

Investasi saham merupakan investasi yang memiliki return dan risiko tinggi, maka dari itu investor harus lebih berhati-hati dalam membuat keputusan investasi sebelum memahami informasi yang berhubungan dengan perusahaan yang menerbitkan saham. Investor perlu melakukan berbagai analisis, baik analisis teknikal maupun analisis fundamental. Analisis tersebut berguna untuk menilai saham-saham yang akan dipilih dan untuk mengetahui tingkat return yang diharapkan dalam menentukan strategi investasi yang akan dilakukan.

Analisis teknikal merupakan studi tentang tindakan atau aksi pasar dengan bantuan grafik-grafik tertentu. Analisis ini dibuat dengan melihat keadaan harga, fluktuasi pasar serta analisis perkiraan menggunakan pola yang dibentuk oleh grafik dan atau perhitungan sistematis mengenai pergerakan harga di waktu lampau sehingga dapat memperkirakan harga di waktu yang akan datang. Analisis fundamental adalah salah satu jenis analisis yang dilakukan investor dengan memperhatikan laporan keuangan dan indikator-indikator fundamental lainnya, seperti pertumbuhan, pembayaran deviden, dan kualitas manajemen perusahaan yang diperkirakan akan mempengaruhi harga saham.

Salah satu perangkat fundamental yang dapat digunakan untuk menilai perusahaan adalah dengan menggunakan metode valuasi relatif. Menurut Werner (2009) valuasi merupakan fokus utama dalam analisis fundamental perusahaan. Metode valuasi relatif digunakan untuk menentukan nilai dari suatu perusahaan dengan cara membandingkan harga saham dengan variabel-variabel relevan yang mempengaruhi nilai saham seperti Price Earnings Ratio membandingkan harga saham dengan laba perusahaan dan Price to Book Value membandingkan harga saham dengan nilai buku perusahaan.
Price to Book Value (PBV) adalah rasio yang digunakan untuk menilai harga suatu saham dengan membandingkan harga pasar saham dengan nilai buku perusahaan (book value). PBV menggambarkan seberapa besar pasar menghargai nilai buku saham suatu perusahaan. Ahmed dan Nanda (2004) dalam Tito,dkk (2007) menunjukkan bahwa hampir semua keputusan investasi di pasar modal didasarkan pada perkembangan PBV. Investor dapat menggunakan rasio PBV untuk menentukan strategi investasi karena dengan menggunakan rasio ini investor dapat memperkirakan saham mana yang harganya wajar, terlalu tinggi (overvalued), atau terlalu rendah (undervalued). Menurut Husnan dan Pudjiastuti (2006) untuk perusahaan-perusahaan yang berjalan dengan baik, pada umumnya rasio PBV mencapai di atas satu, yang menunjukkan bahwa nilai pasar saham lebih besar dari nilai bukunya. Semakin besar rasio PBV semakin tinggi perusahaan dinilai oleh pemodal relatif dibandingkan dengan dana yang ditanamkan di perusahaan.

Hubungan antara harga pasar saham dan nilai buku ini menarik perhatian bagi investor. Harga pasar saham di bawah nilai buku secara umum memberikan informasi kepada investor bahwa saham tersebut undervalued, sehingga saham tersebut merupakan saham yang baik untuk memutuskan investasi jangka panjang. Namun di mata investor, harga pasar mencerminkan potensi perusahaan di masa yang akan datang. Apabila harga pasar berada di bawah nilai bukunya investor memandang bahwa perusahaan tidak cukup potensial (Dwi Prastowo, 2011). Tetapi di sisi lain, Rosenberg, Reid, dan Lanstein dalam Ahmad Rodoni (2005), mengatakan bahwa saham yang memiliki rasio PBV yang rendah akan menghasilkan return yang secara signifikan tinggi dibandingkan saham-saham yang memiliki rasio PBV yang tinggi. Oleh karena itu, menarik sekali 
untuk mengetahui variabel-variabel apakah yang dapat mempengaruhi PBV.

$$
\text { Debt to Equity Ratio (DER) }
$$

merupakan perbandingan antara total hutang dengan total modal sendiri. Pada tingkat tertentu, rasio DER dapat memberikannilai terhadap perusahaankarena digunakan umtuk meningkatkan operasional perusahaan yang kemudian dapat meningkatkan laba. Akan tetapi, rasio DER yang terlalu tinggi mencerminkan total hutang lebih tinggi dibandingkan dengan modal sendiri yang akan mengakibatkan perusahaan akan menanggung biaya modal yang besar untuk membayar hutang tersebut. Semakin tinggi hutang maka risiko yang ditanggung juga besar. Hal ini akan berdampak pada tingkat kepercayaan investor untuk menanamkan modalnya di perusahaan yang ditandai dengan menurunnya harga saham di pasar modal.

Return On Assets (ROA) merupakan rasio profitabilitas untuk mengukur kemampuan perusahaan dalam memanfaatkan aktivanya untuk memperoleh laba. Rasio ini mengukur tingkat kembalian investasi yang telah dilakukan oleh perusahaan dengan menggunakan seluruh dana (aktiva) yang dimilikinya. semakin besar tingkat keuntungan yang dicapai oleh perusahaan maka semakin baik pula posisi perusahaan tersebut dari segi penggunaan asset. Peningkatan daya tarik perusahaan menjadikan perusahaan tersebut makin diminati investor, karena tingkat pengembalian akan semakin besar.

Return On Equity (ROE) merupakan rasio profitabilitas yang mengukur kemampuan perusahaan dalam menghasilkan keuntungan yang tersedia

\section{TELAAH PUSTAKA}

\section{Pengaruh DER terhadap PBV}

Sumber dana perusahaan berasal dari modal yang ditanamkan dari pemilik perusahaan bagi pemegang saham perusahaan. ROE merupakan rasio yang sangat penting bagi pemilik perusahaan karena rasio ini menunjukkan tingkat pengembalian yang dihasilkan oleh manajemen dari modal yang disediakan oleh pemilik perusahaan. Semakin tinggi ROE menunjukkan prospek perusahaan yang semakin baik karena berarti adanya potensi peningkatan keuntungan yang diperoleh perusahaan maka tingkat kepercayaan investor pun akan meningkat sehingga akan mempermudah manajemen perusahaan untuk menarik modal dalam bentuk saham.

Dividen merupakan hak pemegang saham untuk mendapatkan bagian dari keuntungan perusahaan. Salah satu indikator yang menunjukkan besarnya nilai dividen yang dibagikan oleh perusahaan kepada investor adalah Dividend Payout Ratio (DPR). Kebijakan pembayaran deviden mempunyai pengaruh bagi pemegang saham dan perusahaan yang membayar deviden. Para pemegang saham umumnya menginginkan pembagian deviden yang relatif stabil karena dengan kestabilan deviden akan meningkatkan kepercayaan pemegang saham terhadap perusahaan, sehingga mengurangi ketidakpastian pemegang saham dalam menanamkan dananya ke perusahaan. DPRyang berkurang dapat mencerminkan laba perusahaan yang makin berkurang, kondisi seperti ini akan menyebabkan penilaian investor akan suatu saham berkurang. Sebaliknya, semakin tinggi DPR maka para investor akan percaya bahwa perusahaan mengumumkan sinyal positif pada keuntungan yang diharapkan perusahaan sehingga memberikan pengaruh pada peningkatan harga saham

juga sumber dana eksternal yang berasal dari pinjaman pihak ketiga. Menurut 
Mamduh M. Hanafi dan Abdul Halim (2007) Debt to Equity Ratio (DER) mengukur sejauh mana perusahaan untuk memenuhi kewajiban jangka panjangnya. Sedangkan menurut Agus Sartono (2008) DER merupakan rasio hutang terhadap modal yang mengukur seberapa jauh perusahaan dibiayai oleh hutang, dimana semakin tinggi nilai rasio ini menggambarkan gejala yang kurang baik bagi perusahaan. DER merupakan perbandingan antara total hutang dengan total modal sendiri. Pada tingkat tertentu, rasio DER dapat memberikan nilai terhadap perusahaan karena digunakan untuk

\section{Pengaruh ROA terhadap PBV}

Menurut Eduardus Tandelilin (2001) dari sudut pandang investor, salah satu indikator penting untuk menilai prospek perusahaan dimasa datang adalah dengan melihat sejauh mana pertumbuhan profitabilitas perusahaan, salah satunya adalah Return On Asset (ROA). Indikator ini sangat penting diperhatikan untuk mengetahui sejauh mana aktiva yang dimiliki perusahaan bisa menghasilkan laba yang nantinya akan mempengaruhi peningkatan harga saham. Hal ini dapat dipahami bahwa semakin

\section{Pengaruh ROE terhadap PBV}

Return On Equity (ROE) merupakan salah satu rasio profitabilitas yang mengukur kemampuan perusahaan dalam menghasilkan keuntungan yang tersedia bagi pemegang saham perusahaan (Agus Sartono, 2008). Return On Equity (ROE) merupakan rasio yang sangat penting bagi pemilik perusahaan karena rasio ini menunjukkan tingkat pengembalian yang dihasilkan oleh manajemen dari modal yang disediakan oleh pemilik perusahaan. Semakin tinggi ROE menunjukkan prospek perusahaan yang semakin baik karena berarti adanya potensi peningkatan keuntungan yang diperoleh perusahaan meningkatkan operasional perusahaan yang kemudian dapat meningkatkan laba. Akan tetapi, rasio DER yang terlalu tinggi mencerminkan total hutang lebih tinggi dibandingkan dengan modal sendiri yang akan mengakibatkan perusahaan akan menanggung biaya modal yang besar untuk membayar hutang tersebut. Semakin tinggi hutang maka risiko yang ditanggung juga besar. Hal ini akan mempengaruhi tingkat kepercayaan investor untuk menanamkan modalnya di perusahaan yang ditandai dengan menurunnya harga saham di Pasar Modal sehingga akan berpengaruh terhadap Price to Book Value (PBV).

besar tingkat keuntungan yang dicapai oleh perusahaan maka semakin baik pula posisi perusahaan tersebut dari segi penggunaan aset. Peningkatan daya tarik perusahaan menjadikan perusahaan tersebut semakin diminati investor, karena tingkat pengembalian akan semakin besar. Hal ini juga akan berdampak terhadap harga saham dari perusahaan tersebut di Pasar Modal sehingga nilai perusahaan akan semakin baik yang ditandai dengan Price to Book Value (PBV) yang meningkat.

maka tingkat kepercayaan investor pun akan meningkat sehingga akan mempermudah manajemen perusahaan untuk menarik modal dalam bentuk saham. Dengan kata lain, tingkat ROE memiliki hubungan yang positif dengan harga saham, sehingga semakin besar ROE semakin besar pula harga pasar saham, karena besarnya ROE mengindikasikan bahwa tingkat pengembalian yang akan diterima investor akan tinggi sehingga investor akan tertarik untuk membeli saham dan nilai perusahaan akan semakin baik di mata investor yang ditandai dengan Price to Book Value (PBV) yang meningkat. 


\section{Pengaruh DPR terhadap PBV}

Dividend Payout Ratio (DPR) menunjukkan kebijakan perusahaan dalam menghasilkan pembagian dividen kepada para pemegang saham. Kebijakan pembayaran deviden mempunyai pengaruh bagi pemegang saham dan perusahaan yang membayar deviden. Parapemegang saham umumnya menginginkan pembagian deviden yang relatif stabil karena dengan kestabilan deviden akan meningkatkan kepercayaan pemegang saham terhadap perusahaan, sehingga mengurangi

\section{METODE PENELITIAN}

Populasi dalam penelitian ini adalah perusahaan kategori LQ45 yang terdaftar di Bursa Efek Indonesia periode tahun 2010-2013 sebanyak 78 perusahaan dengan pengambilan sampel menggunakan teknik purposive sampling dan sampel yang memenuhi kriteria adalah sebanyak 13 perusahaan. Jenis data yang digunakan adalahdata sekunder yang diperoleh dari website www.idx.co.id.

\section{Operasional Variabel}

\section{Debt to Equity Ratio (DER)}

Debt to Equity Ratio (DER) adalah rasio yang mengukur sejauh mana perusahaan untuk memenuhi kewajiban jangka panjangnya (Mamduh M. Hanafi dan Abdul Halim, 2007:81) yang dapat dirumuskan sebagai berikut:

$$
D E R=\frac{\text { Total Debt }}{\text { Total Equity }}
$$

\section{Return On Assets (ROA)}

Return On Asset (ROA) mengukur kemampuan perusahaan menghasilkan laba dengan menggunakan total aset (kekayaan) yang dipunyai perusahaan setelah disesuaikan dengan biaya-biaya untuk mendanai aset tersebut (Mamduh M. Hanafi dan Abdul Halim, 2007:159) yang dapat dirumuskan sebagai berikut:

$$
R O A=\frac{\text { Laba Bersih }}{\text { Total aset }} \times 100 \%
$$

ketidakpastian pemegang saham dalam menanamkan dananya ke perusahaan. DPR yang berkurang dapat mencerminkan laba perusahaan yang makin berkurang, kondisi seperti ini akan menyebabkan penilaian investor akan suatu saham berkurang. Sebaliknya, semakin tinggi DPR maka para investor akan percaya bahwa perusahaan mengumumkan sinyal positif pada keuntungan yang diharapkan perusahaan sehingga memberikan pengaruh terhadap peningkatan Price to Book Value (PBV).

Teknik analisis dalampenelitian ini menggunakan analisis regresi data panel (fixed effect) yang diaplikasikan dengan software Eviews 7.1. dan uji hipotesis menggunakan t-statistik untuk menguji koefisien regresi parsial serta F-statistik untuk menguji keberartian pengaruh secarasimultan dengan tingkat signifikansi sebesar $5 \%$.

\section{Return On Equity (ROE)}

Return On Equity (ROE) merupakan rasio yang mengkaji sejauh mana suatu perusahaan mempergunakan sumberdaya yang dimiliki untuk mampu memberikan laba atas ekuitas. Semakin tinggi rasio ini semakin baik. Artinya posisi pemilik perusahaan semakin kuat, demikian pula sebaliknya (Kasmir, 2012:204) yang dapat dirumuskan sebagai berikut:

$$
R O E=\frac{E A T}{\text { Equity }} X 100 \%
$$

\section{Dividend Payout Ratio (DPR)}

Rasio pembayaran deviden (dividend payout ratio) merupakan rasio yang mengukur perbandingan dividen terhadap laba perusahaan (Tjiptono Darmadji dan Hendy M. Fakhruddin, 2006:201) yang dapat dirumuskan sebagai berikut:

$$
D P R=\frac{\text { Dividend Per Share }}{\text { Earnings Per Share }} X 100 \%
$$


Price to Book Value (PBV)

Price to Book Value (PBV) merupakan perbandingan antara harga pasar dan nilai

\section{HASIL PENELITIAN DAN PEMBAHASAN \\ Estimasi Model Regresi Data Panel}

Estimasi awal yang dilakukan adalah dengan melakukan Chow-test untuk menentukan pemilihan intercept, yaitu pemilihan antara pooled least square atau fixed effect. Dalam uji ini, hipotesis nol $\left(\mathrm{H}_{0}\right)$ adalah pooled least square sedangkan hipotesis altenatif $\left(\mathrm{H}_{\mathrm{a}}\right)$ adalah fixed effect. Jika $P$-Value $<0,05$ maka $\mathrm{H}_{0}$ ditolak dan $\mathrm{H}_{\mathrm{a}}$ diterima. buku saham (Husnan dan Pudjiastuti, 2006:258) yang dapat dirumuskan sebagai berikut:

$$
P B V=\frac{\text { Harga Pasar }}{\text { Nilai Buku Saham }}
$$

Estimasi selanjutnya yang harus dilakukan bila fixed effect diterima adalah Hausman test sebagai kelanjutan pemilihan intercept, apakah fixed effect atau random effect. Dalam uji ini, hipotesis nol $\left(\mathrm{H}_{0}\right)$ adalah random effect, sedangkan hipotesis alternatif $\left(\mathrm{H}_{\mathrm{a}}\right)$ adalah fixed effect. Jika $P$ Value 0,05 maka $\mathrm{H}_{0}$ ditolak dan $\mathrm{H}_{\mathrm{a}}$ diterima

Tabel 4.9

Redundant Fixed Effects Tests

Equation: Untitled

Test cross-section fixed effects

\begin{tabular}{llll}
\hline \hline Effects Test & Statistic & d.f. & Prob. \\
\hline \hline Cross-section F & 13.427867 & $(12,35)$ & 0.0000 \\
Cross-section Chi-square & 89.619510 & 12 & 0.0000 \\
\hline \hline
\end{tabular}

Sumber : Hasil Perhitungan (Eviews 7.1)

Berdasarkan hasil Chow-test di atas, fixed effect diterima, maka estimasi menunjukkan bahwa Chi-square signifikan atau $P$-Value sebesar 0,0000 lebih kecil dari $5 \%$ sehingga $\mathrm{H}_{0}$ ditolak dan $\mathrm{H}_{\mathrm{a}}$ diterima, selanjutnya, Hausman-test, perlu dilakukan untuk memilih fixed effect atau random effect. 
Tabel 4.10

Uji Hausman-test

Correlated Random Effects - Hausman Test

Equation: Untitled

Test cross-section random effects

\begin{tabular}{llll}
\hline \hline Test Summary & $\begin{array}{l}\text { Chi-Sq. } \\
\text { Statistic }\end{array}$ & Chi-Sq. d.f. & Prob. \\
\hline \hline Cross-section random & 23.406318 & 4 & 0.0001 \\
\hline \hline
\end{tabular}

Cross-section random effects test comparisons:

\begin{tabular}{lllll} 
Variable & Fixed & Random & Var(Diff.) & Prob. \\
\hline \hline DER & 3.649603 & 2.471684 & 0.736477 & 0.1699 \\
ROA & 0.153423 & 0.104485 & 0.000117 & 0.0000 \\
ROE & 0.095022 & 0.228522 & 0.000862 & 0.0000 \\
DPR & -0.001187 & 0.032428 & 0.000088 & 0.0003 \\
\hline \hline
\end{tabular}

Sumber: Hasil Perhitungan (Eviews 7.1)

Hasil pengujian Hausman-test mengikuti fixed effect. Oleh karena itu, menunjukkan signifikan atau atau $P$-Value intercept yang akan digunakan dalam sebesar 0,0001 lebih kecil dari 5\% sehingga pengujian adalah fixed effect. $\mathrm{H}_{0}$ ditolak dan $\mathrm{H}_{\mathrm{a}}$ diterima, maka model

\section{Uji Asumsi Klasik}

\section{Uji Normalitas}

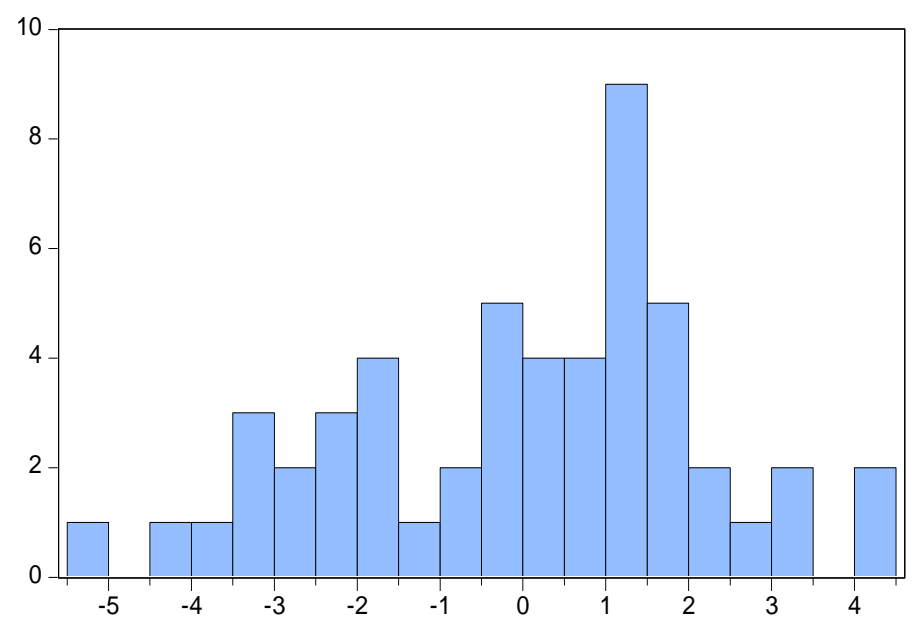

Series: Standardized Residuals Sample 20102013

Observations 52

Mean $\quad-2.33 e-15$

Median $\quad 0.365671$

Maximum $\quad 4.314950$

Minimum $\quad-5.344065$

Std. Dev. $\quad 2.204356$

Skewness $\quad-0.362238$

Kurtosis $\quad 2.602922$

Jarque-Bera 1.478829

Probability $\quad 0.477393$

Gambar 4.1

Normalitas Data 
Dari histogram di atas, dapat dijelaskan bahwa nilai Jarque-Bera adalah sebesar 1,478 sementara nilai Chi-Square pada tabel adalah sebesar 9,488 yang berarti nilai JB lebih kecil dari nilai Chi-Square (JB $\left.1,478<\chi^{2} 9,488\right)$. Kemudian nilai $p$-value sebesar 0,47 lebih besar dari nilai $\alpha=0,05$. Sehingga dapat disimpulkan bahwa data dalam penelitian ini berdistribusi normal.

\section{Uji Multikolinieritas}

Tabel 4.11

Uji Multikolinieritas

\begin{tabular}{|c|c|c|c|c|}
\hline & DER & ROA & ROE & DPR \\
\hline DER & 1.000000 & 0.245239 & 0.571541 & 0.417538 \\
\hline ROA & 0.245239 & 1.000000 & 0.887805 & 0.639702 \\
\hline ROE & 0.571541 & 0.887805 & 1.000000 & 0.731567 \\
\hline DPR & 0.417538 & 0.639702 & 0.731567 & 1.000000 \\
\hline
\end{tabular}

Sumber: Hasil Eviews 7.1

Dari tabel 4.11 di atas dapat dilihat bahwa nilai koefisien korelasinya antar variabel independen dibawah 0,9 dengan demikian data dalam penelitian ini tidak terjadi masalah multikolinieritas.

\section{Uji Heteroskedastisitas}

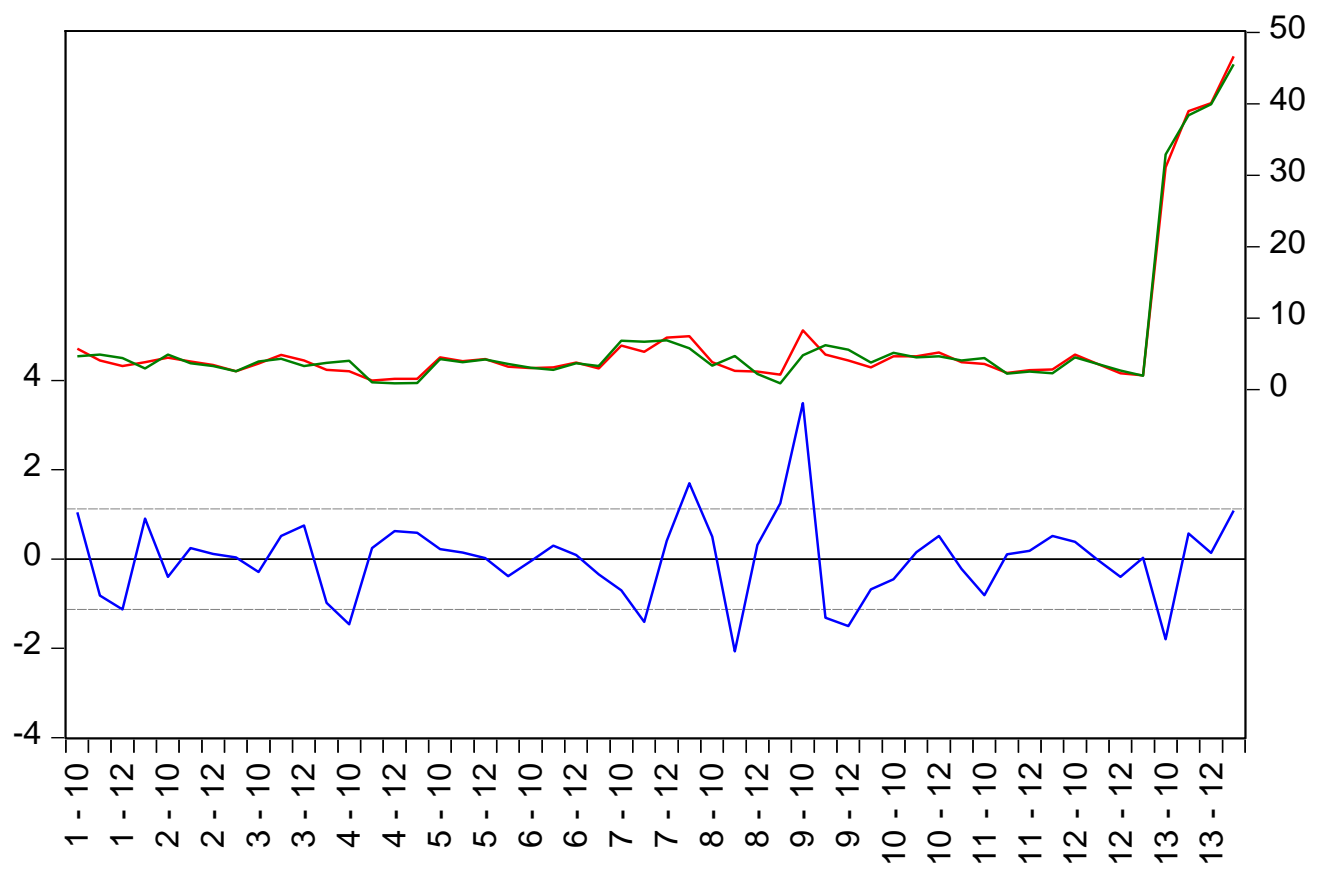

$\longrightarrow$ Residual $\longrightarrow$ Actual $\longrightarrow$ Fitted

Eviews 7.1

Gambar 4.2

Uji Heteroskedastisitas 
Dari grafik di atas diduga tidak terjadi heteroskedastisitas karena grafik residualnya tidak membentuk pola tertentu dengan kata lain residualnya cenderung konstan.

\section{Uji Autokorelasi}

Dependent Variable: PBV

\section{Tabel 4.12}

\section{Uji Autokorelasi}

Method: Panel EGLS (Cross-section weights)

Date: 05/15/15 Time: 07:48

Sample: 20102013

Periods included: 4

Cross-sections included: 13

Total panel (balanced) observations: 52

Linear estimation after one-step weighting matrix

\begin{tabular}{lllll}
\hline \hline Variable & Coefficient & Std. Error & t-Statistic & Prob. \\
\hline \hline C & -1.138026 & 0.928245 & -1.225998 & 0.2284 \\
DER & 3.337059 & 0.795437 & 4.195251 & 0.0002 \\
ROA & 0.174338 & 0.048721 & 3.578271 & 0.0010 \\
ROE & 0.082597 & 0.031706 & 2.605130 & 0.0134 \\
DPR & -0.003270 & 0.006909 & -0.473242 & 0.6390 \\
\hline \hline
\end{tabular}

Effects Specification

\begin{tabular}{llll}
\hline \hline Cross-section fixed (dummy variables) & & \\
\hline \hline & Weighted Statistics & \\
\hline \hline R-squared & 0.988914 & Mean dependent var & 9.499108 \\
Adjusted R-squared & 0.983846 & S.D. dependent var & 8.590987 \\
S.E. of regression & 1.114533 & Sum squared resid & 43.47647 \\
F-statistic & 195.1291 & Durbin-Watson stat & 2.008372 \\
Prob(F-statistic) & 0.000000 & & \\
\hline \hline & Unweighted Statistics & \\
\hline \hline
\end{tabular}

Sumber : Eviews 7.1

Hasil uji DW dapat dilihat pada tabel 4.12 menunjukkan nilai DW sebesar 1,994898. Nilai DW akan dibandingkan dengan nilai tabel dengan menggunakan derajat kepercayaan 5\%, dengan jumlah sampel 52 $(n=52)$ dengan 4 variabel independen $(k=4)$. Maka dari tabel Durbin-Watson akan didapatkan nilai $\mathrm{dl}=1,3929$ dan nilai $\mathrm{du}=1,7223$.
Karena nilai DW terletak diantara batas atas (du) dan batas bawah (4-dl) sehingga suatu persamaan dikatan tidak ada masalah aotukorelasi jika nilai DW berada pada du < DW < 4-dl atau 1,7223 < DW < 4 - 1,3929. Nilai DW adalah sebesar 1,994898, dengan demikian berdasarkan hasil perhitungan uji autokorelasi nilai DW berada diantara $1,7223-2,6071$ sehingga menurut pengujian Durbin-Watson du $<$ DW $<4$-dl 
maka $1,7223<1,9948<2,6071$, dapat disimpulkan bahwa DW-test terletak pada

\section{Model Analisis Regresi Data Panel dengan Pendekatan Efek Tetap (Fixed Effect)}

daerah no auto correlation artinya dalam penelitian ini tidak terjadi autokorelasi.

Hasil estimasi yang diperoleh dari pemilihan intercept adalah dengan menggunakan pendekatan efek tetap (fixed effect) dapat dilihat pada tabel sebagai berikut:

\begin{tabular}{|c|c|c|c|c|}
\hline \multicolumn{5}{|c|}{$\begin{array}{l}\text { Hasil Estimasi Pendekatan } \\
\text { Tabel } \\
\text { Dependent Variable: PBV } \\
\text { Method: Panel Least Squares } \\
\text { Date: } 05 / 15 / 15 \text { Time: 07:06 } \\
\text { Sample: } 20102013 \\
\text { Periods included: } 4 \\
\text { Cross-sections included: } 13 \\
\text { Total panel (balanced) observations: } 52\end{array}$} \\
\hline Variable & Coefficient & Std. Error & t-Statistic & Prob. \\
\hline $\begin{array}{l}\text { C } \\
\text { DER } \\
\text { ROA } \\
\text { ROE } \\
\text { DPR }\end{array}$ & $\begin{array}{l}-1.461156 \\
3.649603 \\
0.153423 \\
0.095022 \\
-0.001187\end{array}$ & $\begin{array}{l}1.475251 \\
1.346998 \\
0.046705 \\
0.044785 \\
0.019501\end{array}$ & $\begin{array}{l}-0.990446 \\
2.709435 \\
3.284950 \\
2.121748 \\
-0.060860\end{array}$ & $\begin{array}{l}0.3288 \\
0.0104 \\
0.0023 \\
0.0410 \\
0.9518\end{array}$ \\
\hline \multicolumn{5}{|c|}{ Effects Specification } \\
\hline \multicolumn{5}{|c|}{ Cross-section fixed (dummy variables) } \\
\hline $\begin{array}{l}\text { R-squared } \\
\text { Adjusted R-squared } \\
\text { S.E. of regression } \\
\text { Sum squared resid } \\
\text { Log likelihood } \\
\text { F-statistic } \\
\text { Prob(F-statistic) }\end{array}$ & $\begin{array}{l}0.990888 \\
0.986723 \\
1.124061 \\
44.22297 \\
-69.57282 \\
237.8812 \\
0.000000\end{array}$ & $\begin{array}{l}\text { Mean de } \\
\text { S.D. dep } \\
\text { Akaike it } \\
\text { Schwarz } \\
\text { Hannan- } \\
\text { Durbin-V }\end{array}$ & $\begin{array}{l}\text { ndent var } \\
\text { dent var } \\
\text { criterion } \\
\text { iterion } \\
\text { inn criter. } \\
\text { son stat }\end{array}$ & $\begin{array}{l}6.525962 \\
9.755120 \\
3.329724 \\
3.967630 \\
3.574282 \\
1.970290\end{array}$ \\
\hline
\end{tabular}

Sumber: Hasil Perhitungan (Eviews 7.1)

Untuk melihat hubungan variabel bebas dengan tingkat signifikansi $95 \%(\alpha=0,05)$. terhadap variabel terikat pada penelitian ini, Berdasarkan hasil estimasi dengan analisis yang digunakan adalah dengan pendekatan data panel dengan metode fixed menggunakan model analisis panel data effect didapat hasil sebagai berikut: dengan metode perhitungan fixed effect

$$
\begin{aligned}
& \mathrm{PBV}_{\mathrm{it}}=-1,461156+3,649603 \mathrm{DER}_{\mathrm{it}}+0,153423 \mathrm{ROA}_{\mathrm{it}}+0,095022 \mathrm{ROE}_{\mathrm{it}}- \\
& 0,001187 D_{P} R_{\text {i }}
\end{aligned}
$$

Dari persamaan 4.1 tersebut dapat diinterpretasikan sebagai berikut:

a. Nilai konstanta sebesar $-1,461156$ menunjukkan bahwa pada saat rasio DER, ROA, ROE, dan DPR sebesar nol maka PBV adalah sebesar $-1,461156$ satuan.

b. Nilai $\beta 1$ positif sebesar 3,649603 menunjukkan bahwa setiap kenaikan 
DER sebesar 1 satuan sedangkan variabel lainnya dianggap konstan, maka akan diikuti dengan kenaikan PBV sebesar 3,649603.

c. Nilai $\beta 2$ positif sebesar 0,153423 menunjukkan bahwa setiap kenaikan ROA sebesar 1 satuan sedangkan variabel lainnya dianggap konstan, maka akan diikuti dengan kenaikan PBV sebesar 0,153423 .

d. Nilai $\beta 3$ positif sebesar 0,095022 menunjukkan bahwa setiap kenaikan
ROE sebesar 1 satuan sedangkan variabel lainnya dianggap konstan, maka akan diikuti dengan penurunan PBV sebesar 0,095022.

e. Nilai $\beta 4$ negatif sebesar $-0,001187$ menunjukkan bahwa setiap kenaikan DPR sebesar 1 satuan sedangkan variabel lainnya dianggap konstan, maka akan diikuti dengan penurunan PBV sebesar $-0,001187$.

\section{Uji Statistik}

\section{Uji t-statistik}

Uji t-statistik dilakukan dengan membandingkan antara t-statistik dengan ttabel. Nilai t-statistik diperoleh dengan program Eviews 7.1. Uji t-statistik dilakukan untuk mengetahui pengaruh variabel independen secara parsial terhadap variabel dependen. Kriteria uji keofisien regresi dari variabel independen terhadap variabel dependen adalah sebagai berikut:
$\mathrm{H}_{0}: \beta_{\mathrm{i}}=0$ : tidak terdapat pengaruh variabel independen terhadap variabel dependen.

$\mathrm{H}_{\mathrm{a}}: \beta_{\mathrm{i}} \neq 0$ : terdapat pengaruh variabel independen terhadap variabel dependen.

Dengan menggunakan taraf keyakinan $95 \%$ $(\alpha=0,05)$ dengan derajat kebebasan $(\mathrm{df})=$ $\mathrm{n}-1=52-1=51$ diperoleh nilai t-tabel sebesar 2,000. Uji untuk setiap variabel bebas pada persamaan 4.1 dapat terlihat pada tabel dibawah ini.

Tabel 4.15

Perbandingan antara $t$-statistik dengan t-tabel

\begin{tabular}{|l|l|l|l|l|}
\hline Variabel & t-statistik & t-tabel $(\alpha=0,05)$ & Prob. & Signifikansi \\
\hline DER & 2,709435 & 2,000 & 0,0104 & Signifikan \\
\hline ROA & 3,284950 & 2,000 & 0,0023 & Signifikan \\
\hline ROE & 2,121748 & 2,000 & 0,0410 & Signifikan \\
\hline DPR & $-2,090957$ & 2,000 & 0,9518 & Tidak Signifikan \\
\hline
\end{tabular}

Sumber : Hasil olah data penulis, 2015

Berdasarkan tabel 4.15 dapat dijelaskan nilai t-statistik dari variabel DER berada pada daerah penolakan hipotesis nol maka $\mathrm{H}_{0}$ ditolak dan $\mathrm{H}_{\mathrm{a}}$ diterima, dengan demikian secara parsial variabel DER berpengaruh secara signifikan terhadap PBV. Variabel ROA secara parsial berpengaruh signifikan terhadap PBV karena berada pada daerah penolakan hipotesis nol maka $\mathrm{H}_{0}$ ditolak dan $\mathrm{H}_{\mathrm{a}}$ diterima. Begitu pula variabel ROE secara parsial berpengaruh signifikan terhadap PBV karena berada pada daerah penolakan hipotesis nol maka $\mathrm{H}_{0}$ ditolak dan $\mathrm{H}_{\mathrm{a}}$ diterima. Kemudian variabel DPR berada pada daerah penerimaan hipotesis nol maka $\mathrm{H}_{0}$ diterima dan $\mathrm{H}_{\mathrm{a}}$ ditolak sehingga secara parsial variabel DPR tidak berpengaruh secara signifikan terhadap PBV. 


\section{Koefisien Determinasi $\left(\mathbf{R}^{\mathbf{2}}\right)$}

Koefisien Determinasi atau $R$ Squared $\left(\mathrm{R}^{2}\right)$ mengukur tingkat bagaimana model dapat dijelaskan dengan baik. Uji ini dilakukan untuk melihat sejauh mana variasi variabel terikat mampu dijelaskan oleh variabel bebasnya. Nilai $\left(\mathrm{R}^{2}\right)$ merupakan fraksi dari variasi yang mampu dijelaskan oleh variabel bebas terhadap variabel terikat.

Berdasarkan hasil pengolahan data yang telah dilakukan dengan menggunakan Eviews 7.1, maka hasil dari koefisien determinasi dapat dilihat pada tabel sebagai berikut.

Tabel 4.24

Koefisien Determinasi $\left(\mathbf{R}^{2}\right)$

Cross-section fixed (dummy variables)

\begin{tabular}{llll}
\hline \hline R-squared & $\mathbf{0 . 9 9 0 8 8 8}$ & Mean dependent var & 6.525962 \\
Adjusted R-squared & 0.986723 & S.D. dependent var & 9.755120 \\
S.E. of regression & 1.124061 & Akaike info criterion & 3.329724 \\
Sum squared resid & 44.22297 & Schwarz criterion & 3.967630 \\
Log likelihood & -69.57282 & Hannan-Quinn criter. & 3.574282 \\
F-statistic & 237.8812 & Durbin-Watson stat & 1.970290
\end{tabular}

Sumber: Hasil Eviews 7.1

Dari tabel di atas maka dapat diketahui nilai koefisien determinasi pada kolom $R$ squaredsebesar 0,990888. Nilai $R$-squared ini menunjukkan besar pengaruh Debt to Equity Ratio, Return On Assets, Return On Equity, dan Dividend Payout Ratio terhadap Price to Book Value. Persentase nilai koefisien determinasi dapat dihitung $(\mathrm{Kd}=$ $\mathrm{R}^{2} \mathrm{x} 100 \%$ ) maka diperoleh $\mathrm{Kd}=0,99 \mathrm{x}$ $100 \%=99 \%$. Koefisien determinasi sebesar 99\% ini menunjukkan bahwa 99\%

perubahan yang terjadi pada Debt to Equity Ratio, Return On Assets, Return On Equity, dan Dividend Payout Ratio. Artinya, Debt to Equity Ratio, Return On Assets, Return On Equity, dan Dividend Payout Ratio mampu memberikan kontribusi atau pengaruh sebesar 99\% terhadap Price to Book Value. Sedangkan sisanya sebesar $1 \%$ dipengaruhi oleh faktor-faktor lain diluar variabel penelitian ini.

\section{Uji F-statistik}

Pengujian pengaruh variabel bebas secara bersama-sama terhadap variabel terikat dilakukan dengan uji F-statistik. Jika nilai F-statistik lebih besar dari pada F-tabel, maka berarti varibel bebas secara bersama-

\section{Tabel 4.25}

Uji F-satistik

Perbandingan antara F-hitung dengan F-tabel

\begin{tabular}{|l|l|l|l|}
\hline F-statistik & F-tabel & Probabilitas & Signifikansi \\
\hline 237,8812 & 2,57 & 0,000000 & Signifikan \\
\hline
\end{tabular}

Sumber : Hasil olah data penulis, 2015

Dari tabel 4.18 dapat dilihat nilai F-statistik sebesar 237,8812 yang lebih besar dari Ftabel sebesar 2,57 (F-statistik=237,8812 > F-tabel=2,57) dengan probabilitas (Fstatistik) sebesar 0,000000 yang lebih kecil dari 0,05. Oleh karena itu, dapat diputuskan bahwa Debt to Equity Ratio (DER), Return On Assets(ROA), Return On Equity (ROE), dan Dividend Payout Ratio (DPR) secara simultan berpengaruh signifikan terhadap Price to Book Value (PBV). 
Analisis Pengaruh Debt to Equity Ratio (X1) terhadap Price to Book Value (Y)

Berdasarkan tabel 4.20 didapat nilai thitung sebesar 2,709435 dengan probabilitas sebesar 0,0104 maka dapat disimpulkan bahwa Debt to Equity Ratio (DER) berpengaruh secara signifikan terhadap Price to Book Value (PBV) dikarenakan nilai t-hitung $>$ t-tabel atau $2,709435>2,000$ dan sig $<0,05$ atau $0,0104<0,05$. Nilai koefisien regresi variabel DER bertanda positif yang berarti bahwa apabila DER meningkat maka akan meningkatkan PBV.

DER merupakan perbandingan antara total hutang dengan total modal. Pada tingkat tertentu, rasio DER dapat memberikan nilai terhadap perusahaan karena digunakan umtuk meningkatkan operasional perusahaan yang kemudian dapat meningkatkan laba. Akan tetapi, rasio DER yang terlalu tinggi mencerminkan total hutang lebih tinggi dibandingkan dengan modal sendiri yang akan mengakibatkan perusahaan akan menanggung biaya modal yang besar untuk membayar hutang tersebut.

Hasil penelitian ini menunjukkan bahwa DER mempunyai pengaruh positif signifikan terhadap PBV. Berdasarkan tabel 4.18 dapat dilihat bahwa rata-rata DER pada Perusahaan LQ45 adalah sebesar 0,68 bahkan nilai DER tertinggi adalah sebesar 2,14 , ini menunjukkan bahwa total hutang lebih besar dibandingkan dengan total modal. Nilai koefisien regresi yang bertanda positif berarti bahwa apabila semakin tinggi DER justru akan meningkatkan PBV. Artinya total hutang yang lebih besar dibandingkan total modal bukan dinilai sebagai sesuatu yang mengkhawatirkan perusahaan. Hal ini menandakan bahwa kebijakan menambah hutang adalah sebagai sinyal pertumbuhan perusahaan. Perusahaan yang sedang mengalami pertumbuhan membutuhkan sumber pendanaan yang lebih besar yang tidak mungkin hanya dapat dipenuhi oleh modal sendiri. Dengan demikian semakin tinggi DER mengindikasikan pertumbuhan perusahaan semakin tinggi sehingga semakin tinggi nilai perusahaan di mata investor akibatnya nilai PBV juga tinggi.

Hasil penelitian ini tidak mendukung hasil penelitian Eva Eko Hidayati (2009) yang menyatakan bahwa DER berpengaruh negatif dan tidak signifikan terhadap PBV. Sebaliknya, hasil penelitian ini mendukung hasil penelitian Tito, dkk (2007) yang menyatakan bahwa DER mempunyai pengaruh positif signifikan terhadap PBV.

Analisis Pengaruh Return On Assets(X2) terhadap Price to Book Value (Y)

Berdasarkan tabel 4.20 didapat nilai thitung sebesar 3,284950 dengan probabilitas sebesar 0,0023 maka dapat disimpulkan bahwa Return On Assets (ROA) berpengaruh secara signifikan terhadap Price to Book Value (PBV) dikarenakan nilai t-hitung $>\mathrm{t}$-tabel atau $3,284950>2,000$ dan sig $<0,05$ atau 0,0023 $<0,05$. Nilai koefisien regresi variabel ROA bertanda positif yang berarti bahwa apabila ROA meningkat maka akan meningkatkan PBV.

ROA merupakan salah satu rasio profitabilitas. Dari sudut pandang investor, salah satu indikator untuk menilai prospek perusahaan di masa yang akan datang adalah dengan melihat sejauh mana pertumbuhan profitabilitas perusahaan (Eduardus Tandelilin, 2001). Hasil penelitian ini menujukkan bahwa ROA mempunyai pengaruh positif signifikan terhadap PBV. Adanya pengaruh positif signifikan ini memunginkan peningkatan daya tarik perusahaan yang makin diminati investor sehingga harga saham akan meningkat, dan meningkatnya harga saham akan meningkatkan nilai perusahaan. Dengan demikian, semakin besar tingkat 
laba yang dicapai oleh perusahaan, maka semakin baik pula posisi perusahaan dari penggunaan aset sehingga nilai perusahaan juga akan meningkat yang ditandai dengan meningkatnya PBV.

Hasil penelitian ini tidak mendukung hasil penelitian Tito, dkk (2007) yang menunjukkan bahwa besarnya ROA tidak mempengaruhi besarnya PBV. Sebaliknya, hasil penelitian ini mendukung hasil penelitian Fadli (2010) yang menunjukkan bahwa ROA mempunyai pengaruh yang signifikan terhadap PBV.

\section{Analisis Pengaruh Return On Equity(X3)} terhadap Price to Book Value (Y)

Berdasarkan tabel 4.20 didapat nilai thitung sebesar 2,121748 dengan probabilitas sebesar 0,0410 maka dapat disimpulkan bahwa Return On Equity (ROE) berpengaruh secara signifikan terhadap Price to Book Value (PBV) dikarenakan nilai t-hitung $>\mathrm{t}$-tabel atau $2,121748>2,000$ dan sig $<0,05$ atau $0,0410<0,05$. Nilai koefisien regresi variabel ROE bertanda positif yang berarti bahwa apabila ROE meningkat maka akan meningkatkan PBV.

ROE merupakan rasio yang mengukur kemampuan perusahaan dalam menghasilkan keuntungan yang tersedia bagi para pemegang saham (Agus Sartono, 2008). Rasio ini sangat penting bagi pemilik perusahaan karena rasio ini menunjukkan tingkat pengembalian yang dihasilkan oleh manajemen dari modal yang disediakan oleh pemilik perusahaan. Hasil penelitian ini menemukan bahwa ROE mempunyai pengaruh positif signifikan terhadap PBV. Artinya semakin tinggi ROE maka semakin tinggi pula PBV sebagai ukuran dari nilai perusahaan. Dengan demikian, besarnya ROE mengindikasikan bahwa pengembalian yang akan diterima investor akan tinggi sehingga investor akan tertarik untuk membeli saham kemudian harga saham akan meningkat, dan meningkatnya harga saham maka akan meningkatkan nilai perusahaan yang ditandai dengan meningkatnya PBV.

Hasil penelitian ini tidak mendukung hasil penelitian Fadli (2010) yang menyatakan bahwa ROE tidak mempunyai pengaruh yang signifikan terhadap PBV. Sebaliknya, hasil penelitian ini mendukung hasil penelitian Eva Eko Hidayati (2009) yang menyatakan bahwa ROE berpengaruh positif signifikan terhadap PBV.

\section{Analisis Pengaruh Dividend Payout Ratio(X4) terhadap Price to Book Value (Y)}

Berdasarkan tabel 4.20 didapat nilai thitung sebesar $-2,090957$ dengan probabilitas sebesar 0,9518 maka dapat disimpulkan bahwa Dividend Payout Ratio (DPR) berpengaruh tidak signifikan terhadap Price to Book Value (PBV) dikarenakan nilai t-hitung $>\mathrm{t}$-tabel atau 2,090957 >2,000dan sig > 0,05 atau 0,9518 $>0,05$. Nilai koefisien regresi variabel DPR bertanda negatif yang berarti bahwa apabila DPR meningkat maka PBV akan menurun. DPR menunjukkan kebijakan perusahaan dalam menghasilkan pembagian deviden kepada para pemegang saham. Pembagian deviden ini memberikan informasi atau isyarat mengenai kinerja finansial perusahaan menurut pandangan para investor. Semakin tinggi DPR maka akan menguntungkan pemegang saham, tetapi di sisi lain pilihan untuk membagi laba dalam bentuk deviden akan mengurangi sumber dana intern perusahaan, jika perusahaan menginvestasikan kembali labanya dalam bentuk laba ditahan maka akan memperkuat posisi keuangan perusahaan dalam menghadapi kesulitan keuangan di masa yang akan datang.

Hasil penelitian ini menunjukkan bahwa DPR mempunyai pengaruh negatif tidak signifikan terhadap PBV. Berdasarkan tabel 4.18 dapat dilihat bahwa rata-rata DPR pada Perusahaan LQ45 adalah sebesar $52,27 \%$. Ini menunjukkan DPR yang relatif besar yang dikhawatirkan terjadinya risiko 
likuiditas keuangan perusahaan yang tinggi. Semakin tinggi DPR artinya deviden yang dibagikan tinggi maka akan semakin besar kas yang dibutuhkan perusahaan untuk membayar deviden akibatnya laba ditahan akan semakin kecil. Hal ini menyebabkan berkurangnya kesempatan perusahaan untuk menginvestasikan kembali labanya sehingga pertumbuhan perusahaan bisa saja melemah. Jika pertumbuhan perusahaan rendah maka para investor menangkap sebagai sinyal negatif dari perusahaan

\section{PENUTUP}

\section{Kesimpulan}

Berdasarkan analisis data yang telah dilakukan untuk mengetahui pengaruh Debt to Equity Ratio (DER), Return On Assets (ROA), Return On Equity (ROE), dan Dividend Payout Ratio (DPR) terhadap Price to Book Value (PBV) pada perusahaanLQ45 yang terdaftar di Bursa Efek Indonesia selama periode tahun 2010 sampaidengan tahun 2013, maka dapat ditarik kesimpulan sebagai berikut:

\section{Saran}

a. Untuk meningkatkan minat investor dalam berinvestasi, sebaiknya perusahaan memperhatikan dengan baik rasio-rasio keuangan seperti rasio Debt to Equity Ratio(DER), Return On Assets (ROA), Return On Equity(ROE), dan Dividend Payout Ratio(DPR) serta rasio lainnya yang dapat berpengaruh terhadap Price to Book Value(PBV) yang menjadi penilaian investor terhadap perusahaan untuk berinvestasi.

b. Bagi investor, dalam memberikan penilaian terhadap suatu perusahaan sebaiknya juga memperhatikan faktor lain yang mempengaruhi nilai suatu sehingga akan berdampak pada berkurangnya minat investor akibatnya harga saham pun akan menurun demikian pula PBV akan menurun.

Hasil penelitian ini tidak mendukung hasil penelitian Ika dan Shiddiq (2013) yang menyatakan bahwa DPR berpengaruh positif signifikan terhadap PBV. Sebaliknya, hasil penelitian ini mendukung hasil penelitian Eva Eko Hidayati (2009) yang menyatakan bahwa DPR berpengaruh negatif tidak signifikan terhadap PBV.

a. Debt to Equity Ratio (DER) berpengaruh positif signifikan terhadap Price to Book Value (PBV)

b. Return On Assets (ROA) berpengaruh positif signifikan terhadap Price to Book Value (PBV)

c. Return On Equity (ROE) berpengaruh positif signifikan terhadap Price to Book Value (PBV)

d. Dividend Payout Ratio (DPR) berpengaruh negatif tidak signifikan terhadap Price to Book Value (PBV)

perusahaan dan disarankan untuk berinvestasi pada saham PT. Unilever Indonesia, Tbk. (UNVR) karena saham tersebut merupakan saham yang mempunyai rasio DER, ROA, ROE, dan DPR yang paling tinggi diantara saham lainnya.

c. Bagi peneliti selanjutnya diharapkan menggunakan jenis perusahaan yang berbeda dan menggunakan ruang lingkup sampel yang lebih luas. Selain itu, diharapkan juga dapat menambah variabel-variabel yang dapat mempengaruhi nilai perusahaan. 


\section{DAFTAR PUSTAKA}

Agus Sartono. 2008. Manajemen Keuangan Teori dan Aplikasi. Edisi 4. Yogyakarta: BPFE.

Bambang Riyanto. 2008. Dasar-Dasar Pembelanjaan Perusahaan. Edisi 4. Yogyakarta: BPFE.

Brigham, Eugene $F$ dan Joel $F$ Houston. 2001. Manajemen Keuangan. Buku I Edisi Kedelapan. Jakarta: Erlangga.

David S. K dan Kurniawan I. 2010. Manajemen Investasi: Pendekatan Teknikal dan Fundamental Untuk Analisis Saham. Edisi Pertama. Yogyakarta: Graha Ilmu.

Dwi Prastowo. 2011. Analisa Laporan Keuangan. Edisi Ketiga. Yogyakarta: YKPN.

Hartono Jogiyanto. 2003. Teori Portofolio dan Analisis Investasi. Edisi 3. Yogyakarta : BPFE Yogyakarta.

Hartono Jogiyanto. 2013. Teori Portofolio dan Analisis Investasi. Edisi 8. Yogyakarta : BPFE Yogyakarta.

Husein Umar. 2008. Desain Penelitian Akuntansi Keprilakuan. Jakarta: Rajagrafindo Persada.

Irham Fahmi. 2012. Pengantar Pasar Modal. Bandung: Alfabeta CV.

Jerry J. Weygant. Et.al. 2013. Accounting Principles. Edisi 7 Jilid 1. Jakarta: Salemba Empat.

K.R. Subramanyam dan John J. Wild. 2013. Analisis Laporan Keuangan. Buku 1 Edisi 10. Jakarta: Salemba Empat.

Kasmir. 2012. Analisis Laporan Keuangan. Jakarta: Rajagrafindo.
Lukman Syamsuddin. 2011. Manajemen Keuangan Perusahaan. Jakarta: Rajawali Pers.

Mamduh M. Hanafi dan Abdul Halim. 2007. Analisis Laporan Keuangan. Yogyakarta: UPP STIM YKPN.

Mohamad Samsul. 2006. Pasar Modal dan Manajemen Portofolio. Jakarta: Erlangga.

Munawir. 2007. Analisa Laporan Keuangan.Yogyakarta: Penerbit Liberty.

Pandji Anoraga dan Piji Pakarti. 2006. Pengantar Pasar Modal. Cetakan Kelima. Jakarta: Rineka Cipta.

Riahi, Ahmed Belkaoui. 2006. Accounting Theory : Teori Akuntansi. Edisi 5. Jakarta: Penerbit Salemba Empat.

Rodoni, Ahmad. 2005. Analisis teknikal dan Fundamental pada Pasar Modal. Jakarta: CSES Press.

Sofyan Syafri Harahap. 2012. Teori Akuntansi. Jakarta: Raja Grafindo Persada.

Suad Husnan dan Enny Pudjiastuti. 2006. Dasar-dasar Manajemen Keuangan. Edisi Kelima.Yogyakarta: UPP STIM YKPN.

Sugiyono. 2010. Statistika Untuk Penelitian. Yogyakarta: Alfabeta.

Sujoko Efferin, dkk. 2008. Metode Penelitian Akuntansi : Mengungkap Fenomena dengan Pendekatan Kuantitatif dan Kualitatif.. Yogyakarta: Graha Ilmu.

Sunariyah. 2006.2 Pengantar Pengetahuan Pasar Modal. Edisi Kelima. Yogyakarta: UPP STIM YKPN. 
Tandelilin, Erduardus. 2001. Analisis Investasi dan Manajemen Portofolio. Edisi 1. Yogyakarta: BPFE.

Tjiptono Darmaji dan Hendy M. Fakhruddin. 2006. Pasar Modal di Indonesia. Jakarta: Salemba empat.

Walter T. Harrison Jr. Et.al. 2012. Akuntansi Keuangan (International Financial Reporting StandardsIFRS). Edisi Kedelapan Jilid 1. Jakarta: Erlangga.

Werner R. Muhardi. 2009. Analisis Saham Pendekatan Fundamental. Cetakan Pertama. Jakarta: PT. Indeks.

Durrotun Nasehah dan Endang Tri Widyarti. 2012. Pengaruh ROE, DER, DPR, Growth Dan Firm Size Terhadap Price To Book Value (PBV) (Studi Kasus pada Perusahaan Manufaktur yang Listed di BEI Periode Tahun 2007-2010). Journal Of Management. Volume 1, Nomor 1, Tahun 2012, Halaman 1-9.

Ika dan Shiddiq. 2013. Analisis Pengaruh Profitabilitas, Kebijakan Deviden, Kebijakan Utang, Dan Kepemilikan Manajerial Terhadap Nilai Perusahaan (Studi Empiris Pada Perusahaan Manufaktur Yang Terdaftar Di Bursa Efek Indonesia Periode 2009 - 2011). Journal Of Accounting Volume 2, Nomor 2, Tahun 2013, Halaman 1 - 10.
Tito Perdana Putra, dkk. 2007.Pengaruh Kinerja Keuangan Dan Beta Saham Terhadap Price To Book Value (Studi Pada Perusahaan Real Estate Dan Property Yang Listed Di Bursa Efek Indonesia Periode Tahun 20042006). Jurnal Studi Manajemen \& Organisasi Volume 4, Nomor 2, Juli, Tahun 2007, Halaman 81.

http://www.idx.co.id

http://www.sahamoke.com 